\title{
ANALISIS KANDUNGAN UNSUR HARA MAKRO DAN MIKRO PADA KOMPOS CAMPURAN KULIT PISANG DAN CANGKANG TELUR AYAM
}

\author{
Abdul Gani*, Siska Widiyanti, Sulastri \\ Jurusan Pendidikan Kimia FKIP Universitas Syiah Kuala, Banda Aceh, Indonesia \\ *email: abdulgani051266@gmail.com
}

Received 24 November 2020

Accepted 24 June 2021

\begin{abstract}
Abstrak
Penelitian tentang analisis kandungan unsur hara makro dan mikro pada kompos campuran kulit pisang dan cangkang telur ayam bertujuan untuk mengetahui kadar unsur hara yang terkandung pada kompos yang dihasilkan dalam penelitian ini. Proses pembuatan kompos dilakukan dengan menggunakan bahan kulit pisang dan cangkang telur ayam yang telah dihaluskan dan ditambahkan EM-4 ke dalam wadah, terdiri atas 3 variasi dan 2 kali ulangan. Total berat komposisi tiap variasi yaitu $4 \mathrm{~kg}$. Pengomposan berlangsung selama 31 hari. Setelah kompos matang, dilakukan pengujian terhadap $\mathrm{pH}$ dan kandungan hara $\mathrm{C}$ orgnaik, nitrogen, kalium, phosfor, kalsium dan rasio $\mathrm{C} / \mathrm{N}$ di laboratorium. Pengujian $\mathrm{pH}$ menunjukkan tingkat $\mathrm{pH}$ tergolong basa yaitu pada skala 10 dan 11 . Hasil uji anova pada parameter $\mathrm{C}$-organik, $\mathrm{N}$ dan rasio $\mathrm{C} / \mathrm{N}$ menunjukkan adanya pengaruh antara variasi bahan pupuk organik terhadap kandungan hara pupuk organik. Hasil uji anova pada parameter $\mathrm{P}, \mathrm{K}$ dan $\mathrm{Ca}$ tidak menunjukkan adanya pengaruh antara variasi bahan pupuk organik terhadap kandungan hara pupuk organik. Hasil rata-rata analisis nitrogen (\% W/W) perlakuan 1, 2 dan 3 secara berurutan adalah 0,$51 ; 0,22$; dan 0,23 . Hasil rata-rata analisis C-organik (\% W/W) secara berturut-turut adalah 33,83; 8,03; dan 5,25. Kadar rata-rata phosfor $(\% \mathrm{~W} / \mathrm{W})$ secara berturut-turut adalah 1,$15 ; 0,34$; dan 0,69 . Kandungan rata-rata kalium (\% W/W) sebesar 2,79; 1,13; dan 0,82. Kadar rata-rata kalsium (\% W/W) secara berurutan 21,$41 ; 21,42$; dan 27,46. Rata-rata rasio $\mathrm{C} / \mathrm{N}$ (\%) yang diperoleh secara berurutan, yaitu 67,06; 36,5; dan 22,87. Parameter analisis untuk P dan K menunjukkan kesesuaian dengan ketentuan SNI kompos.
\end{abstract}

Keywords: Kulit pisang, cangkang telur ayam, EM-4, pupuk kompos, unsur hara

\begin{abstract}
Research on the analysis of macro and micro nutrient content in the compost mixture of banana peels and chicken egg shells aims to determine the nutrient content of the compost produced in this study. The process of making compost is carried out using banana peels and chicken eggshells that have been mashed and added EM-4 into the container, consisting of 3 variations and 2 replications. The total composition weight for each variation is $4 \mathrm{~kg}$. Composting lasts 31 days. After the compost is cooked, the $\mathrm{pH}$ and nutrient content of Corganic, nitrogen, potassium, phosphorus, calcium and $\mathrm{C} / \mathrm{N}$ ratio are tested in the laboratory. The $\mathrm{pH}$ test shows that the $\mathrm{pH}$ level is classified as alkaline, namely on a scale of 10 and 11. Anova test results on the $\mathrm{C}$-organic parameter, The $\mathrm{N}$ and $\mathrm{C} / \mathrm{N}$ ratio showed the influence between the variation of organic fertilizer on the nutrient content of organic fertilizers. Anova test results on the parameters $\mathrm{P}, \mathrm{K}$ and $\mathrm{Ca}$ did not show any influence between the variation of organic fertilizer on the nutrient content of organic fertilizers. The average results of nitrogen analysis $(\% \mathrm{~W} / \mathrm{W})$ of treatments 1,2 and 3 were $0.51 ; 0.22$; and 0.23 . The mean results of the $\mathrm{C}$-organic analysis (\% W/W) were 33.83, respectively; 8,03 ; and 5.25. The average levels of phosphorus $(\%)$ were $1.15 ; 0.34$; and 0.69 . The average potassium content $(\% \mathrm{~W} / \mathrm{W})$ was $2.79 ; 1.13$; and 0.82 . The mean calcium levels $(\% \mathrm{~W} / \mathrm{W})$ were $21.41 ; 21.42$; and 27.46 . The average $\mathrm{C} / \mathrm{N}$ ratio $(\%)$ obtained sequentially, namely
\end{abstract}


67.06; 36.5; and 22.87. The analysis parameters for $\mathrm{P}$ and $\mathrm{K}$ indicate conformity with the compost SNI provisions.

Keywords: Banana peels, egg shells, EM-4, organic fertilizers, nutrients

\section{Pendahuluan}

Limbah merupakan suatu permasalahan yang akan berdampak buruk bagi lingkungan, seperti limbah rumah tangga, kota, penjual makanan maupun minuman yang menghasilkan limbah salah satunya ialah limbah yang berasal dari penjual pisang goreng, nasi goreng dan martabak telur. Penjual pisang goreng menghasilkan limbah berupa kulit pisang. Berdasarkan hasil survey dari penjual pisang goreng yang berada di Darussalam dan Lamgugop, pedagang dapat menghabiskan 3-5 tandan pisang, sehingga akan menghasilkan limbah kulit pisang yang banyak. Begitu pula dengan penjual martabak telur dan nasi goreng setiap pedagang dapat menghabiskan tiga papan telur, sehingga akan menghasilkan limbah cangkang telur yang banyak.

Limbah-limbah tersebut jika tidak ditangani dengan serius akan menimbulkan beberapa kerugian, seperti menumpuknya volume sampah di TPA, menimbulkan bau yang tidak sedap, merusak lingkungan serta dapat menjadi sumber penyakit. Zeng, dkk., (2015), menyatakan bahwa limbah cangkang telur yang dibiarkan begitu saja akan menghasilkan emisi gas yang bau selama masa biodegradasi sehingga akan menimbulkan polusi udara. Alternatif dari pengurangan limbah cangkang telur dapat dilakukan dengan memanfaatkan limbahlimbah tersebut menjadi produk bernilai ekonomis.

Peneliti sebelumnya juga telah memanfaatkan limbah kulit pisang dalam pembuatan permen (Willar, dkk., 2014), minuman probiotik (Idayati, dkk., 2016), keripik dan kue donat (Wakano, dkk., 2016) dan pupuk organik cair (Rambitan \& Sari, 2013). Pada penelitian ini akan memanfaatkan limbah kulit pisang dan cangkang telur dalam pengomposan. Hal ini dikarenakan kulit pisang dan cangkang telur memiliki kandungan hara yang dibutuhkan oleh tanaman. Penelitian yang dilakukan oleh Nasrun, dkk., (2016) menghasilkan kadar nitrogen yang diperoleh pada galon pertama dengan menggunakan EM-4 $200 \mathrm{ml}$, aquadest 800 $\mathrm{ml}$ dan molase $80 \mathrm{ml}$, dan waktu fermentasi 7, 14 dan 21 hari, masing-masing sebesar $1,26 \%, 1,82 \%$ dan $1,42 \%$. Kadar kalium menggunakan EM-4 200 ml dengan waktu yang berbeda yaitu 7 hari kadar $\mathrm{K}_{2} \mathrm{O}$ adalah $0,586 \%$, hari ke 14 kadar $\mathrm{K}_{2} \mathrm{O}$ yang didapat yaitu $0,598 \%$, hari ke 21 kadar $\mathrm{K}_{2} \mathrm{O}$ yang dihasilkan yaitu $0,60 \%$.

Proses pengolahan kulit pisang menjadi kompos, dilakukan dengan cara kulit pisang terlebih dahulu diubah menjadi bentuk pasta. Bentuk pasta yang lengket akan menghambat aerasi dan kerja mikroorganisme. Untuk mempermudah proses pengomposan ditambahkan serbuk cangkang telur guna mempermudah proses penyerapan aktivator. Hal ini dikarenakan cangkang telur memiliki pori-pori alami yang dapat menyerap komponen tertentu. Maslahat, dkk., (2015), cangkang telur memiliki kadar kalsium yang cukup tinggi sehingga memiliki potensi untuk menjadi penyerap atau sorben.

Selain untuk mempermudah proses penyerapan aktivator, cangkang telur ayam juga mengandung hara yang dibutuhkan tanaman. Hal ini dapat dilihat dari hasil penelitian Ryan (2012) dalam Noviansyah dan Chalimah (2015) berdasarkan penelitiannya menghasilkan tanaman cabai yang paling tinggi dengan perlakuan pemberian pupuk organik yang mengandung ekstrak kulit telur kering.

Hal ini disebabkan karena ekstrak kulit telur kering mengandung kalsium (Ca) yang merupakan unsur hara yang dibutuhkan tanaman selain nitrogen, posfor, kalium, magnesium, dan belerang. Berdasarkan penelitian yang dilakukan Rahmadina, dkk., (2017) kadar unsur hara untuk pupuk dari cangkang telur yaitu $\mathrm{N}$ 
0,18\% (sedang), kadar P 7\% (sedang), dan kadar K 8\% (sedang), zat C - Organik 5,2 $\%$ (sangat tinggi), C/N 30 (sangat tinggi).

Pupuk yang mengandung hara kalsium sangat dibutuhkan oleh tanaman, karena kalsium pada tanaman berperan dalam menutrisi pertumbuhan dan perkembangan terutama pada akar dan tunas. Jika tanaman kekurangan kalsium maka akan menyebabkan tanaman menjadi kerdil, terhambatnya pertumbuhan pucuk dan dapat menyebabkan bunga pada tanaman gugur (Syam, dkk., 2014). Pupuk kaya kalsium biasanya digunakan untuk tanaman hias dan tanaman yang menghasilkan buah, karena peran kalsium yang mampu merangsang pertumbuhan buah dan bunga pada tanaman. Pernyataan ini didukung oleh Rachma, dkk., (2017) penggunaan pupuk kalsium berpengaruh nyata terhadap kualitas buah tomat serta didukung oleh hasil penelitian Syam, dkk., (2014) pemberian serbuk cangkang telur ayam berpengaruh nyata terhadap pertumbuhan tinggi tanaman kamboja jepang. (Nurjayanti, dkk., 2012), tepung cangkang telur ayam diperkirakan mengandung kalsium $(\mathrm{Ca})$ dan magnesium (Mg) yang dapat meningkatkan $\mathrm{pH}$ tanah.

Campuran kulit pisang dan cangkang telur ayam dinilai cukup efektif sebagai bahan pembuatan kompos, kulit pisang merupakan bahan yang mudah membusuk sedangkan cangkang telur merupakan bahan yang sukar membusuk, sehingga dengan mencampurkan kedua bahan tersebut diperkirakan akan meningkatkan laju pembusukan saat proses pengomposan berlangsung.

Proses pengomposan secara alami memerlukan waktu sekitar 2-3 bulan, sehingga perlu ditambahkan biodekomposer yang merupakan zat pengurai organisme yang sudah mati. Biodekomposer biasanya berupa bakteri, jamur pembusuk, serangga dan lain sebagainya. Contoh produk bakteri pengurai yang dijual di pasar sangat beragam seperti M-BIO, Green Phoskko, OrgaDec, Stardec, SuperDec, Harmony,
Spidey, Cacing tanah dan EM-4 (Direktorat Perbenihan dan Sarana Produksi Direktorat Jendral Hortikultura Depertemen Pertanian, 2008).

Penelitian ini menggunakan bakteri pengurai EM-4, karena harganya yang terjangkau serta mudah ditemukan di toko pertanian. Mulyani (2014), pengomposan dengan menggunakan EM4 dapat memberikan keuntungan seperti berkurangngnya bau bususk dan panas yang keluar dari tumpukan sampah, dan sampah dapat dijadikan kompos dalam jangka waktu hanya 2 minggu.

Jumlah mikroorganisme fermentasi dalam EM4 sangat banyak sekitar 80 jenis, dan dapat digolongkan menjadi : bakteri fotosintetik, Lactobacillus sp (bakteri asam laktat) Streptomyces sp (peracun terhadap hama penyakit), ragi (pereduksi), Actinomycetes (antibiotic) (Direktorat Pembenihan dan Sarana Produksi, 2008). Fan, dkk, (2017) kompos yang dihasilkan dengan penambahan EM-4 menghasilkan kandungan hara nitrogen, phosfor dan kalium yang lebih tinggi daripada kompos tanpa penambahan EM-4. Lebih lanjut Subandryo, dkk., (2017) menyatakan bahwa penggunaan EM-4 dapat meningkatkan unsur hara kompos.

\section{Metode Penelitian}

\section{Bahan dan Peralatan}

Bahan-bahan yang digunakan antara lain limbah kulit pisang, limbah cangkang telur ayam, bakteri EM-4, air, asam sulfat $97 \%\left(\mathrm{H}_{2} \mathrm{SO}_{4}\right)$, selenium ( $\left.\mathrm{Se}\right)$, tembaga (II) sulfat $\left(\mathrm{CuSO}_{4}\right)$, natrium sulfat $\left(\mathrm{Na}_{2} \mathrm{SO}_{4}\right)$, natrium hidroksida $(\mathrm{NaOH})$, asam borat $\left(\mathrm{H}_{3} \mathrm{BO}_{3}\right)$, kalium bikromat $\left(\mathrm{K}_{2} \mathrm{Cr}_{2} \mathrm{O}_{7}\right)$, besi (II) sulfat $\left(\mathrm{FeSO}_{4}\right)$, asam fosfat $\left(\mathrm{H}_{3} \mathrm{PO}_{4}\right)$, asam nitrat $\left(\mathrm{HNO}_{3}\right) 65 \%$, asam perklorat $\left(\mathrm{HClO}_{4}\right) 70 \%$, asam klorida ( $\mathrm{HCl})$ ammonium heptamolibdat $\left(\left(\mathrm{NH}_{4}\right)_{6} \mathrm{Mo}_{7} \mathrm{O}_{24}\right)$, kalium antimoniltartrat $\left(\mathrm{C}_{8} \mathrm{H}_{10} \mathrm{~K}_{2} \mathrm{O}_{15} \mathrm{Sb}_{2}\right)$, asam askorbat $\left(\mathrm{C}_{8} \mathrm{H}_{8} \mathrm{O}_{6}\right)$, asam borat $\left(\mathrm{H}_{3} \mathrm{BO}_{3}\right)$, bromcresol green (BCG), etanol $\left(\mathrm{C}_{2} \mathrm{H}_{5} \mathrm{OH}\right)$, selenium (Se), natrium hidroksida $(\mathrm{NaOH})$. Sedangkan alat-alat yang digunakan adalah 
pisau, blender, timbangan, takaran air, wadah pengomposan, pengaduk, termometer, neraca analitik, disgestion apparatus, unit destilator, dispenser, Erlenmeyer $100 \mathrm{~mL}$, labu Kjedahl, tabung dan block digester, labu ukur $50 \mathrm{ml}$, vortex mixer, pipet volum, buret, statif, pipet tetes, flame fotometer, spektrofotometri UV-vis dan AAS.

\section{Proses Pembuatan Kompos}

Limbah kulit pisang dibersihkan keemudian dihaluskan menggunakan blender dengan perbandingan volume kulit pisang dan air 2:1. Cangkang telur ayam dibersihkan dengan air mengalir, kemudian dikeringkan dan dihaluskan menggunakan alat penghalus. Sampel terdiri dari 3 variasi dan 2 kali ulangan (Tabel 1.)

Tabel 1. Komposisi bahan baku kompos

\begin{tabular}{|c|c|c|c|c|}
\hline Ulangan & Varian & $\mathbf{P}_{1}$ & $\overline{\mathbf{P}_{2}}$ & $\overline{P_{3}}$ \\
\hline \multirow{3}{*}{\multicolumn{2}{|c|}{$\overline{\mathbf{U}_{1}}$}} & - $4 \mathrm{~kg} \mathrm{KP}$ & $-3 \mathrm{~kg} \mathrm{KP}$ & $-2 \mathrm{~kg} \mathrm{KP}$ \\
\hline & & - $\quad 4 \mathrm{ml} \mathrm{EM}-4$ & $-\quad 1 \mathrm{~kg} \mathrm{CT}$ & $-\quad 2 \mathrm{~kg} \mathrm{CT}$ \\
\hline & & & - $\quad 4 \mathrm{ml} \mathrm{EM}-4$ & - $\quad 4 \mathrm{ml} \mathrm{EM}-4$ \\
\hline \multirow{3}{*}{\multicolumn{2}{|c|}{$\mathbf{U}_{2}$}} & - $\quad 4 \mathrm{~kg} \mathrm{KP}$ & $-\quad 3 \mathrm{~kg} \mathrm{KP}$ & $-\quad 2 \mathrm{~kg} \mathrm{KP}$ \\
\hline & & - $\quad 4 \mathrm{ml} \mathrm{EM-4}$ & $-\quad 1 \mathrm{kgCT}$ & $-\quad 2 \mathrm{kgCT}$ \\
\hline & & & - $\quad 4 \mathrm{ml} \mathrm{EM}-4$ & - $\quad 4 \mathrm{ml} \mathrm{EM}-4$ \\
\hline \multirow[t]{3}{*}{ Keterangan: } & $\bar{U}$ & : ulangan & \multirow{3}{*}{\multicolumn{2}{|c|}{$\begin{array}{l}\text { KP : kulit pisang } \\
\mathrm{CT}: \text { cangkang telur }\end{array}$}} \\
\hline & $\mathrm{P}$ & : perlakuan & & \\
\hline & $\mathrm{EM}-$ & : effective mi & & \\
\hline
\end{tabular}

Masing-masing sampel dimasukkan dalam wadah pengomposan. Pengukuran suhu dilakukan setiap hari. Proses pengomposan berlangsung selama 31 hari. Kompos yang sudah matang di isolasi, kemudian dilakukan uji kandungan hara N, P, K dan Ca di laboratorium.

\section{Analisis Karbon (C-Organik)}

Timbang 1,00 g tanah kering udara $<2 \mathrm{~mm}$ dan pindahkan ke labu berbentuk kerucut leher lebar $500 \mathrm{ml}$. Tambahkan 10 ml larutan 0,17 $\mathrm{M} \mathrm{K}_{2} \mathrm{Cr}_{2} \mathrm{O}_{7}$, labu perlahan dikocok untuk mencampurkan tanah di dalam larutan. Tambahkan $20 \mathrm{ml} \mathrm{H}_{2} \mathrm{SO}_{4}$ (95-97\%). Putar labu sampai tanah dan reagen tercampur selama 1 menit. Diamkan labu selama 30 menit. Tambahkan $200 \mathrm{ml}$ air dan biarkan dingin. Tambahkan $10 \mathrm{ml}$ $\mathrm{H}_{3} \mathrm{PO}_{4} 85 \%$ dan sesaat sebelum titrasi tambahkan $3 \mathrm{~mL}$ indikator barium difenilamin sulfonat. Titrasi larutan dengan $1 \mathrm{M} \mathrm{FeSO}_{4}$. Selama titrasi, warna berubah dari coklat menjadi ungu dan berkedip menjadi hijau pada titik akhir. Saat titik akhir semakin dekat, warna violet memudar.

Keterangan:

$$
\operatorname{Kadar} \text { C-organik }(\%)=\frac{\frac{b-s \times 3}{b}}{w} \times \mathrm{M}
$$

$\mathrm{b}=\mathrm{mL} \mathrm{FeSO}_{4}$ yang digunakan dalam penentuan blanko

$\mathrm{s} \quad=\mathrm{mL} \mathrm{FeSO}_{4}$ yang digunakan dalam penentuan sampel

$3=$ berat setara karbon

$\mathrm{w} \quad=$ berat tanah

$\mathrm{M} \quad$ = faktor koreksi

Analisis Kadar Nitrogen 
Sampel pupuk ditimbang sebanyak $1 \mathrm{~g}$ kemudian ditambahkan $1 \mathrm{~g}$ selenium dan $20 \mathrm{~mL} \mathrm{H}_{2} \mathrm{SO}_{4}$. Panaskan tabung dengan hati-hati di block digester pada suhu sekitar $300{ }^{\circ} \mathrm{C}$ sampai digesti berwarna putih atau hijau pucat kemudian didihkan perlahan selama 30 menit. Lepaskan tabung dari block digester dan biarkan dingin. Setelah dingin, tambahkan sedikit demi sedikit, $100 \mathrm{ml}$ dengan air agar tidak mengkristal, aduk dan diamkan hingga cairannya jernih. Siapkan penampung destilat yaitu campuran $25 \mathrm{ml}$ asam borat dan 8 tetes larutan indikator ke dalam labu erlenmeyer $100 \mathrm{ml}$ dan tempatkan ini di bawah kondensor peralatan distilasi sehingga ujung kondensor berada di bawah permukaan larutan. Larutan didestilasi dengan menambahkan $30 \mathrm{ml} \mathrm{NaOH} 30 \%$. Lanjutkan distilasi selama 2 menit setelah tetes distilasi pertama telah mencapai larutan indikator asam borat dalam labu erlenmeyer. Titarasi larutan dengan 0,002 $\mathrm{M} \mathrm{KH}\left(\mathrm{IO}_{3}\right)_{2}$ hingga warna berubah dari hijau menjadi merah. Ulangi perlakuan untuk membuat uji blanko. Kadar nitrogen dihitung menggunakan persamaan berikut:

$\operatorname{Kadar} \mathrm{N}(\%)=\frac{(\mathrm{s}-\mathrm{b}) \times \mathrm{m} \times 14 \times \frac{100}{\mathrm{v}} \times 100}{\mathrm{w}} \times m \ldots \ldots \ldots \ldots \ldots \ldots \ldots \ldots \ldots \ldots \ldots \ldots \ldots \ldots$

Keterangan:

$\mathrm{s}=\mathrm{mL} \mathrm{KH}\left(\mathrm{IO}_{3}\right)_{2}$ yang digunakan untuk titrasi sampel

$\mathrm{b}=\mathrm{mL} \mathrm{KH}\left(\mathrm{IO}_{3}\right)_{2}$ yang digunakan untuk titrasi blanko

$\mathrm{m} \quad=$ molaritas $\mathrm{KH}\left(\mathrm{IO}_{3}\right)_{2}$

$14=$ bobot setara nitrogen

$\mathrm{v} \quad=\mathrm{mL}$ filtrat

$100=$ konversi ke \%

$\mathrm{W}=$ berat tanah

$\mathrm{M} \quad$ = faktor koreksi

Analisis Kadar Phosfor dan Kalium

Sampel kompos yang telah dihaluskan dimasukkan dalam labu kjedahl sebanyak 0,5 g. Tambahkan $5 \mathrm{~mL} \mathrm{HNO}_{3}$ dan $0,5 \mathrm{~mL} \mathrm{HClO}_{4}$, dikocok dan dibiarkan selama 12 jam. Panaskan pada block digestor mulai suhu $100^{\circ} \mathrm{C}$, setelah uap kuning habis suhu dinaikkan hingga $200^{\circ} \mathrm{C}$. Proses destruksi selesai bila sudah keluar uap putih dan cairan dalam labu tersisa sekitar 0,5 mL. Dinginkan dan encerkan dengan $\mathrm{H}_{2} \mathrm{O}$ hingga volume menjadi $50 \mathrm{~mL}$ kemudian dikocok sampai homogen dan disaring dengan kertas saring W-41 agar didapat ekstrak jernih (ekstrak A).

Pengukuran kadar $\mathrm{K}$ dilakukan dengan cara pipet $1 \mathrm{~mL}$ ekstrak A lalu masukkan dalam tabung reaksi volume 20 mL, tambahkan $9 \mathrm{~mL}$ aquades, kocok dengan vortex mixer sampai homogen.ekstrak yang dihasilkan dari pengenceran 10x disebut ekstrak B. Ukur absorbansi $\mathrm{K}$ dalam ekstrak $\mathrm{B}$ menggunakan AAS dengan deret standard campuran I sebagai pembanding, dicatat absorbansi baik standard maupun sampel. Pengukuran kadar $\mathrm{P}$ dilakukan dengan cara pipet $1 \mathrm{~mL}$ ekstrak $\mathrm{B}$, masukkan dalam tabung reaksi $20 \mathrm{~mL}$. Tambahkan masingmasing $9 \mathrm{~mL}$ pereaksi pembangkit warna ke dalam setiap sampel dan deret standard. Kocok dengan vortex mixer sampai homogen. Biarkan 15-25 menit kemudian diukur dengan spektrofotometri pada panjang gelombang $693 \mathrm{~nm}$. Hitunglah kadar phosfor dan kalium dalam sampel kompos dengan menggunakan persamaan berikut.

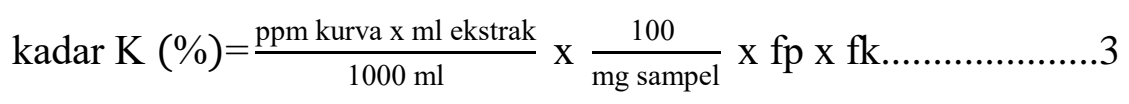




$$
\operatorname{kadar} \mathrm{P}(\%)=\frac{\text { ppm kurva } \mathrm{x} \mathrm{ml} \mathrm{ekstrak}}{1000 \mathrm{ml}} \times \frac{100}{\mathrm{mg} \text { sampel }} \times \mathrm{fp} \times \frac{31}{95} \mathrm{fk} \ldots \ldots \ldots \ldots . . . .4
$$

Keterangan:

$\begin{array}{lll}\text { ppm kurva }= & \text { kadar sampel yang didapat dari kurva regresi hubungan } \\ & & \text { antara deret standard dengan pembacaannya setelah dikurangi blanko } \\ \mathrm{fp} & \text { faktor pengenceran (bila ada) } \\ \mathrm{fk} & \text { faktor koreksi kadar air }=100 /(100-\% \text { kadar air }) \\ 100 & =\text { faktor konversi ke } \% \\ 31 & =\text { bobot atom } \mathrm{P} \\ 95 & =\text { bobot molekul } \mathrm{PO}_{4}\end{array}$

\section{Analisis Kadar Kalsium}

Sampel kompos yang telah dihaluskan ditimbang sebanyak 5 gram. Sampel diarangkan diatas hot plate, lalu diabukan dalam tanur dengan temperatur awal $100^{\circ} \mathrm{C}$ dan perlahan-lahan temperatur dinaikkan hingga suhu $500^{\circ} \mathrm{C}$ dengan interval setiap 5 menit. Sampel yang sudah dilakukan pengabuan didinginkan dalam desikator. Abu ditambahkan $5 \mathrm{~mL}$ asam nitrat (1:1), kemudian diuapkan dalam hot plate sampai kering. Sampel dimasukkan kembali dalam tanur dengan temperatur awal $100^{\circ} \mathrm{C}$ dan perlahan-lahan temperatur dinaikkan hingga suhu $500^{\circ} \mathrm{C}$ dengan interval setiap 5 menit.

Sampel hasil destruksi dilarutkan dalam $5 \mathrm{~mL}$ asam nitrat $(1: 1)$ dalam labu ukur $100 \mathrm{~mL}$, tambahka akuabides sampai tanda batas. Sampel disaring dengan kertas Whatman No. 42. Larutan baku kalsium $(1000 \mu / \mathrm{ml})$ yang telah disiapkan dipipet sebanyak $0,5 \mathrm{~mL}$ dan dimasukkan ke dalam labu ukur $50 \mathrm{~mL}$ lalu diecncerkan dengan akuabides hingga tanda batas. Larutan yang sudah diencerkan dipipet masingmasing $0.5 \mathrm{~mL} ; 1,0 \mathrm{~mL} ; 1,5 \mathrm{~mL} ; 2,0 \mathrm{~mL}$; dan 2,5 mL dimasukkan dalam labu ukur $25 \mathrm{~mL}$ dan diencerkan dengan akuabides hingga tanda batas, sehingga diperoleh larutan dengan konsentrasi $0,2 \mu \mathrm{g} / \mathrm{mL} ; 0,4$ $\mu \mathrm{g} / \mathrm{mL} ; 0,6 \mu \mathrm{g} / \mathrm{mL} ; 0,8 \mu \mathrm{g} / \mathrm{mL}$; dan 1,0 $\mu \mathrm{g} / \mathrm{mL}$. Larutan tersebut diukur pada panjang gelombang $422,7 \mathrm{~nm}$ dengan tipe nyala udara-asetelin.
Larutan sampel hasil destruksi dipipet sebanyak $1 \mathrm{ml}$ dimasukkan ke dalam labu ukur $100 \mathrm{~mL}$ dan diencerkan dengan akuabides hingga tanda batas. Lalu dipipet $1 \mathrm{~mL}$ dimasukkan ke dalam labu ukur $50 \mathrm{~mL}$ (faktor pengenceran $=5000$ kali). Diukur abasorbansi pada panjang gelombang 422,7 nm. Nilai absorbansi yang diperoleh harus berada dalam rentang kurva kalibrasi larutan baku kalsium. Konsentrasi kalsium dalam sampel dihitung berrdasarkan persamaan garis regresi dan kurva kalibrasi.

\section{Analisis Data}

Analis data dilakukan menggunakan analysis of varience (Anova) dengan signifikansi $\mathrm{p}<0,05$. Analisis statistik dilakukan dengan menggunakan statistical packge for social sciences (SPSS) 18.

\section{Hasil dan Pembahasan}

\section{Proses Pembuatan Kompos}

Proses pembuatan kompos dilakukan terlebih dahulu dengan menghaluskan kulit pisang dan cangkang telur ayam. Selama proses pengomposan berlangsung, terjadi perubahan fisik dari bahan baku yang digunakan. Perubahan fisik kompos dapat dilihat pada Gambar 1. 

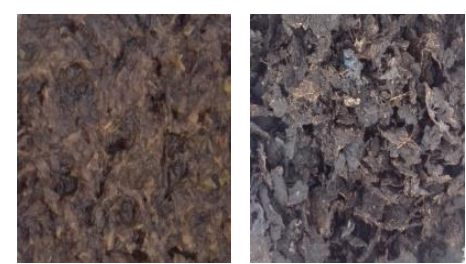

(a)
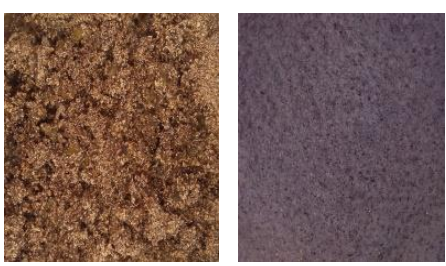

(b)
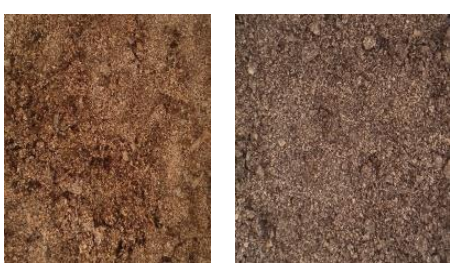

(c)

Gambar 1. Fisik kompos ; a) kompos variasi 1 hari ke-0 (kiri) sampai hari ke-31 (kanan), b) kompos variasi 2 hari ke-0 (kiri) sampai hari ke-31 (kanan) c)kompos variasi 3 hari ke-0 (kiri) sampai hari ke-31 (kanan)

Perubahan fisik kompos dapat lihat berdasarkan warna, aroma dan teksturnya. Warna merupakan salah satu parameter yang menunjukkan tingkat kematangan kompos. Kompos dikatakan matang apabila memilik warna coklat kehitaman sampai hitam. Minggu pertama dalam proses pengomposan masing-masing variasi mengalami perubahan secara fisik, yaitu pasta kulit pisang pada perlakuan pertama mengeluarkan air, hal ini dikarenakan perlakuan 1 merupakan kontrol yang tidak diberikan serbuk cangkang telur ayam.

Perlakuan 2 dan 3 tidak mengeluarkan air karena diberikan tambahan serbuk cangkang telur ayam sehingga air yang terkandung dalam pasta kulit pisang diserap oleh serbuk cangkang telur. Hal ini dikarenakan cangkang telur memiliki pori-pori alami yang dapat menyerap komponen tertentu. Pori-pori alami cangkang telur merupakan zat yang sangat memungkinkan untuk dijadikan adsorben. Maslahat, dkk., (2015), cangkang telur memiliki kadar kalsium yang cukup tinggi sehingga memiliki potensi untuk menjadi penyerap atau sorben.

Selain perubahan fisik tersebut, kompos juga mengeluarkan bau yang menyengat. Minggu kedua masing-masing perlakuan mengeluarkan ulat dan aroma yang menyengat. Selama proses pengomposan sekitar \pm 4 minggu, masingmasing perlakuan mulai berubah warna menjadi coklat kehitaman serta bau menyengat mulai menghilang.

\section{Pengukuran $\mathrm{pH}$}

Hasil pengukuran $\mathrm{pH}$ yang diperoleh pada variasi pupuk $\mathrm{P}_{1} \mathrm{U}_{1}, \mathrm{P}_{1} \mathrm{U}_{2}$, $\mathrm{P}_{2} \mathrm{U}_{1}, \mathrm{P}_{2} \mathrm{U}_{2}, \mathrm{P}_{3} \mathrm{U}_{1}$, dan $\mathrm{P}_{3} \mathrm{U}_{2}$ berturut-turut sebesar $10 ; 10 ; 11 ; 11 ; 11$; dan 11 . Berdasarkan data perolehan $\mathrm{pH}$ tersebut, dapat disimpulkan bahwa $\mathrm{pH}$ pupuk organik yang terbentuk bersifat basa, hal ini terlihat dari rentang $\mathrm{pH}$ yang diperoleh yaitu pada tingkat 10 dan 11 dari rentang $\mathrm{pH}$ 14. SNI telah menetapkan $\mathrm{pH}$ kompos yang memenuhi syarat yaitu beradaoada rentang 6,80-7,49, maka $\mathrm{pH}$ kompos yang dihasilkan pada penelitian ini belum memenuhi SNI. Terbentuknya $\mathrm{pH}$ basa pada sampel diduga disebabkan oleh sampel yang digunakan yaitu cangkang telur mengandung $\mathrm{Ca}$ yang merupakan basa kuat.

\section{Pengukuran Suhu Harian}

Pengukuran suhu dilakukan setiap hari menggunakan termometer alkohol. Perolehan suhu diubah ke dalam bentuk grafik yang menghubungkan rentang suhu kompos (sumbu y) terhadap lama waktu terbentuknya pupuk organik (sumbu x). 


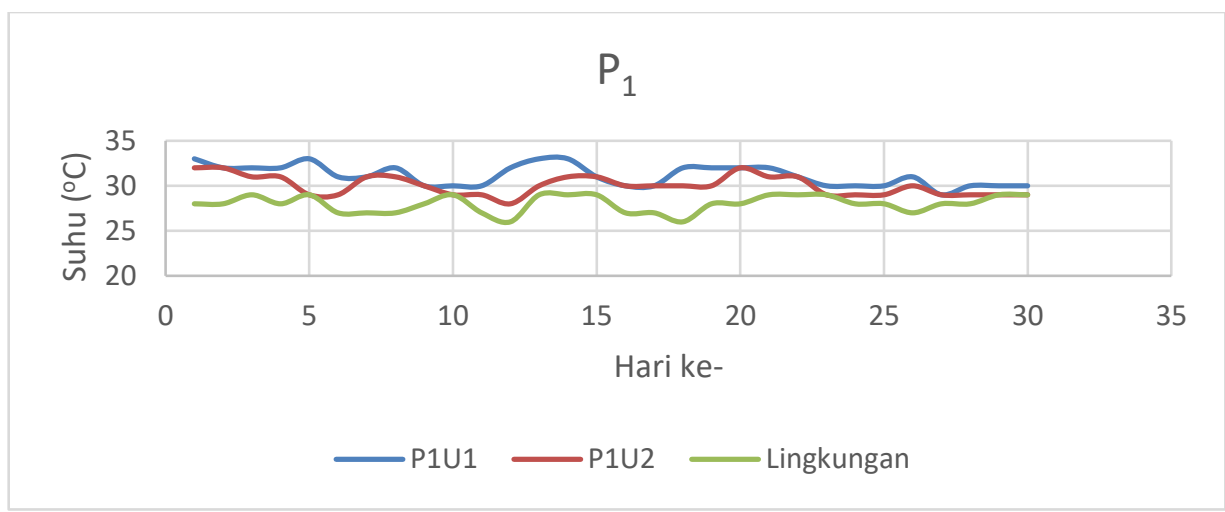

(a)

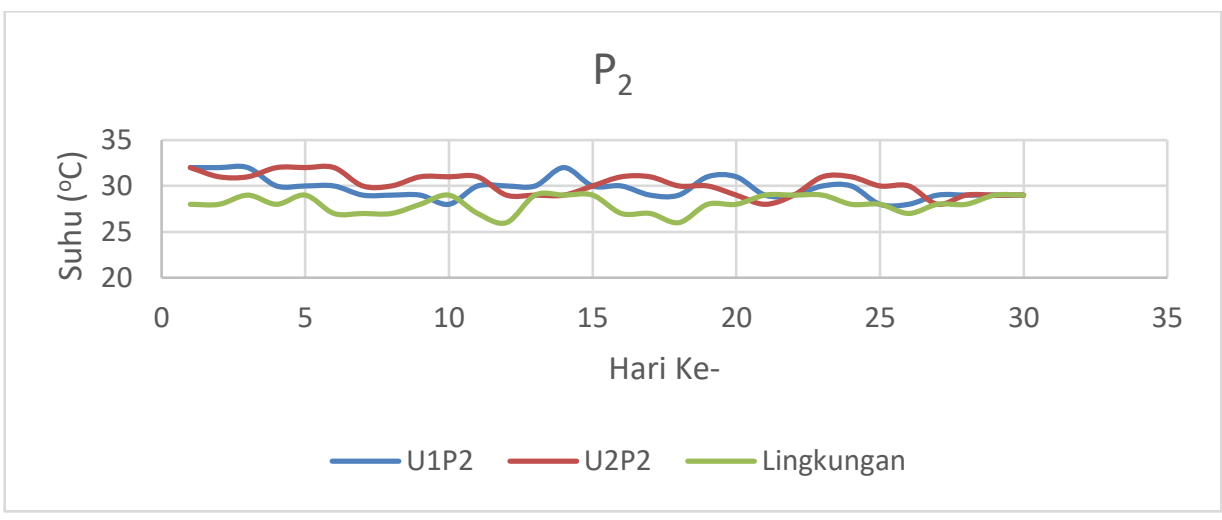

(b)

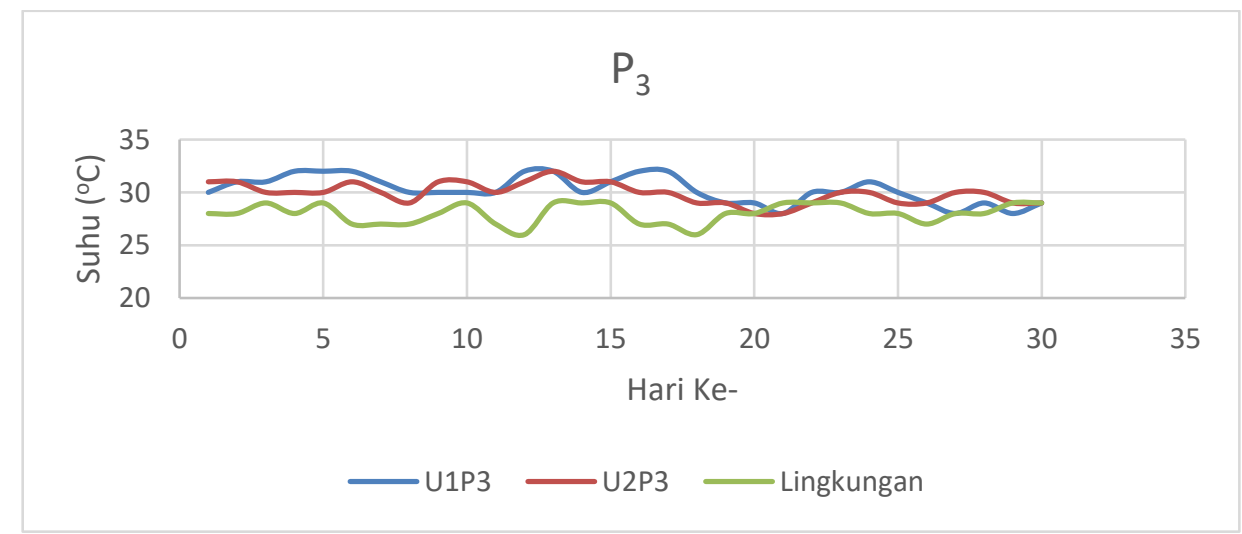

(c)

Gambar 2. Suhu harian kompos ; a) kompos variasi 1, b) kompos variasi 2, c) kompos variasi 3

Berdasarkan Gambar 2. yang sudah disajikan, suhu yang didapatkan dalam penelitian tidak menghasilkan peningkatan yang signifikan. Hal tersebut diduga karena terjadinya sirkulasi suhu yang teratur dari lubang udara pada wadah pengomposan. Peningkatan suhu dapat terjadi karena adanya aktivitas bakteri dalam proses 
pengomposan karena melepaskan sebagian energi dari penguraian bahan organik. Suhu pupuk apabila mendekati tingkat kematangannya maka akan semakin menurun mengikuti suhu lingkungan sekitar.

Widarti, dkk., (2015) pada umumnya suhu dalam proses pengomposan merupakan kombinasi antara suhu termofilik dan mesofilik. Suhu mesofilik merupakan suhu dimana mikroorganisme mesofilik hidup pada suhu $10-40^{\circ} \mathrm{C}$ dan bertugas memperkecil ukuran partikel bahan organik sehingga luas permukaan bertambah dan mempercepat proses pengomposan. Mikroorganisme termofilik hidup pada suhu $45-60^{\circ} \mathrm{C}$ dan bertugas mengkonsumsi karbohidrat dan protein sehingga bahan kompos dapat terdegrasi dengan cepat (Irawan, 2014).

Suhu pupuk pada setiap variasi berkisar antara $28-33^{\circ} \mathrm{C}$, tidak mencapai fase termofilik. Hal ini diduga karena tumpukan pupuk yang terlalu rendah sehingga tidak mampu menahan panas. Widarti, dkk., (2015), ketinggian tumpukan kompos yang baik adalah $1-2,2$ meter dan tinggi maksimum adalah 1,5 1,8 meter. Penelitian yang dilakukan oleh Sahwan, (2010) diperoleh data suhu selama proses pengomposan yang sesuai yaitu kombinasi antara suhu mesofilik dan termofilik. Hal ini diduga karena tumpukan kompos yang tinggi sehingga dapat menahan panas yang dihasilkan selama proses pengomposan.

\section{Analisis Kandungan Hara Makro dan Mikro}

Kandungan hara yang di analisis pada penelitian ini antara lain nitrogen, karbon, phosfor, kalium, kalsium dan rasio $\mathrm{C} / \mathrm{N}$. Berikut disajikan perbandingan hasil analisis kandungan unsur hara kompos dengan SNI pada Tabel 3.

Tabel 3. Perbandingan Analisis Kandungan Unsur Hara dengan SNI

\begin{tabular}{|c|c|c|c|c|c|c|c|c|}
\hline \multirow{3}{*}{ No. } & \multirow{3}{*}{ Parameter } & \multicolumn{3}{|c|}{$\begin{array}{c}\text { Kandungan Unsur Hara } \\
(\%)\end{array}$} & \multirow{3}{*}{$\begin{array}{l}\text { Rata- } \\
\text { rata }\end{array}$} & \multicolumn{2}{|c|}{ SNI } & \multirow{3}{*}{ Keterangan } \\
\hline & & \multirow{2}{*}{ Perlakuan } & \multicolumn{2}{|c|}{ Ulangan } & & \multirow{2}{*}{$\begin{array}{l}\text { Min } \\
(\%)\end{array}$} & \multirow{2}{*}{$\begin{array}{c}\text { Maks } \\
(\%)\end{array}$} & \\
\hline & & & 1 & 2 & & & & \\
\hline \multirow{4}{*}{1.} & \multirow{4}{*}{$\mathrm{N}$} & 1 & 0,46 & 0,55 & 0,51 & \multirow{3}{*}{0,4} & \multirow{3}{*}{ - } & Bagus \\
\hline & & 2 & 0,22 & 0,22 & 0,22 & & & Tidak Bagus \\
\hline & & 3 & 0,24 & 0,22 & 0,23 & & & Tidak Bagus \\
\hline & & 1 & 31,22 & 36,44 & 33,83 & \multirow{3}{*}{9,8} & \multirow{3}{*}{32} & Tidak Bagus \\
\hline \multirow[t]{3}{*}{2.} & \multirow{3}{*}{$\mathrm{C}$} & 2 & 7,50 & 8,56 & 8,03 & & & Tidak Bagus \\
\hline & & 3 & 5,28 & 5,22 & 5,25 & & & Tidak Bagus \\
\hline & & 1 & 0,59 & 0,56 & 1,15 & \multirow{4}{*}{0,1} & \multirow{4}{*}{ - } & Bagus \\
\hline \multirow[t]{3}{*}{3.} & \multirow[t]{3}{*}{$\mathrm{P}$} & 2 & 0,36 & 0,32 & 0,34 & & & Bagus \\
\hline & & 3 & 0,39 & 0,30 & 0,69 & & & Bagus \\
\hline & & 1 & 3,94 & 1,65 & 2,79 & & & Bagus \\
\hline \multirow[t]{3}{*}{4.} & K & 2 & 1,03 & 1,23 & 1,13 & \multirow[t]{3}{*}{0,2} & \multirow[t]{3}{*}{ - } & Bagus \\
\hline & & 3 & 0,89 & 0,75 & 0,82 & & & Bagus \\
\hline & & 1 & 25,68 & 17,13 & 21,41 & & & Bagus \\
\hline \multirow[t]{3}{*}{5.} & $\mathrm{Ca}$ & 2 & 20,92 & 21,92 & 21,42 & \multirow[t]{3}{*}{ - } & \multirow[t]{3}{*}{25,5} & Bagus \\
\hline & & 3 & 30,32 & 24,95 & 27,64 & & & Tidak Bagus \\
\hline & & 1 & 67,87 & 66,25 & 67,06 & & & Tidak Bagus \\
\hline \multirow[t]{2}{*}{6.} & Rasio C/N & 2 & 34,09 & 38,91 & 36,5 & \multirow[t]{2}{*}{10} & \multirow[t]{2}{*}{20} & Tidak Bagus \\
\hline & & 3 & 22 & 23,73 & 22,87 & & & Tidak Bagus \\
\hline
\end{tabular}




\section{Kandungan Nitrogen}

Analisis nitrogen (\%) variasi pupuk 1, 2, dan 3 rata-rata secara berurutan adalah $0.51 ; 0,22$; dan 0,23. Kandungan $\mathrm{N}$ yang memenuhi syarat SNI adalah pupuk variasi 1 sebesar $0,51 \%$. Pupuk variasi 1 merupakan kontrol, yaitu pupuk tanpa penambahan cangkang telur. Variasi 2 dan 3 merupakan pupuk dengan penambahan cangkang telur menghasilkan kadar $\mathrm{N}$ yang belum memenuhi syarat SNI. Rendahnya kandugan $\mathrm{N}$ yang dihasilkan diduga karena aktivator yang sudah berhenti bekerja, sehingga sisa-sisa bahan organik yang belum dirombak oleh bakteri tidak dapat dirombak. Berhentinya proses pembusukan juga bisa dapat disebabkan oleh rendahnnya konsentrasi aktivator yang digunakan sehingga pertumbuhan bakteri terhambat.

\section{Kandungan Phosfor}

Hasil analisis phosfor (\%) variasi pupuk 1, 2, dan 3 rata-rata secara berurutan adalah 1,15;0,34; dan 0,69. Berdasarkan perolehan data tersebut, maka kandungan phosfor $(\mathrm{P})$ pada pupuk sudah memenuhi syarat minimum yang telah ditetapkan oleh SNI yaitu sebesar $0,10 \%$. Menurut Widarti, dkk., (2015), unsur ini sangat penting didalam proses fotosintesis. Berdasarkan hasil uji anova, komposisi bahan baku yang berbeda tiap perlakuan tidak memberikan adanya pengaruh kadar phosfor yang dihasilkan.

\section{Kandungan Kalium}

Berdasarkan Tabel 3, kandungan kalium pada kompos sudah memenuhi syarat SNI yang ditetapkan yaitu sebesar $0,2 \%$, maka sampel pupuk organik yang diuji sudah memenuhi syarat kelayakan kandungan kalium. Kalium dalam tanah sebagian besar tidak dapat terserap langsung oleh tanaman. Oleh karena itu, ke dalam tanah masih perlu ditambahkan pupuk buatan (Purnomo, Sutrisno, \& Sumiyati, 2017). Berdasarkan hasil uji anova, komposisi bahan baku yang berbeda tiap perlakuan tidak memberikan adanya pengaruh terhadap kadar kalium yang dihasilkan.

\section{Kandungan Karbon}

Hasil analisis karbon (\%) variasi pupuk 1, 2, dan 3 rata-rata secara berurutan adalah 33,83; 8,03; dan 5,25. Kadar Corganik yang dihasilkan pada pupuk organik belum memenuhi standar SNI. Pada perlakuan pertama kadar C-organik tergolong sangat tinggi bahkan di atas batas maksimum kadar C-organik, sedangkan pada perlakuan 2 dan 3 tergolong rendah. Kandungan C-organik tidak mempengaruhi kualitas tanaman yang ditanam, namun kualitas tanaman lebih dominan dipengaruhi oleh asupan hara yang diberikan pada saat pemupukan (Purnomo, Sutrisno \& Sumiyati, 2017). Berdasarkan hasil uji anova, komposisi bahan baku yang berbeda tiap perlakuan memberikan adanya pengaruh terhadap kadar karbon yang dihasilkan.

\section{Kandungan Kalsium}

Hasil analisis kalsium (\%) variasi pupuk 1, 2, dan 3 rata-rata secara berurutan adalah 21,41; 21,42; dan 27,42. Variasi 1 dan 2 sudah memenuhi standar yang ditetapkan oleh SNI yaitu maksimum $25 \%$, sedangkan pada perlakuan 3 tergolong tinggi diatas batas maksimum yang ditetapkan oleh SNI. Berdasarkan hasil uji anova, komposisi bahan baku yang berbeda tiap perlakuan tidak memberikan adanya pengaruh terhadap kadar kalsium yang dihasilkan. Namun, pada perlakuan 3 mengahasilkan kadar kalsium yang tinggi. Hal ini dikarenakan pada perlakuan 3 penambahan cangkang telur ayam lebih banyak dari pada perlakuan 1 dan 2. Syam, dkk., (2015) Sekitar 95\% dari cangkang telur kering mengandung kalsium karbonat dengan berat 5,5 gram.

\section{Rasio C/N}

Rasio $\mathrm{C} / \mathrm{N}$ merupakan indikator dari kematangan dan kualitas pupuk. Semakin tinggi rasio $\mathrm{C} / \mathrm{N}$ suatu bahan organik, maka waktu yang dibutuhkan 
dalam proses penguraiannya juga semakin lama. Rasio $\mathrm{C} / \mathrm{N}$ dari masing-masing variasi pupuk 1, 2, dan 3 rata-rata secara berurutan adalah 67; 36,5; dan 22,87. Berdasakan standar yang sudah ditetapkan oleh SNI, yaitu berada diantara rentang 1020. Maka, rasio $\mathrm{C} / \mathrm{N}$ pada pupuk tergolong tinggi, hal ini disebabkan karena kandungan nitrogen yang rendah dan kandungan karbon pada beberapa sampel pupuk tergolong tinggi.

Berdasarkan hasil uji anova, komposisi bahan baku yang berbeda tiap perlakuan memberikan adanya pengaruh terhadap rasio $\mathrm{C} / \mathrm{N}$ yang dihasilkan. Perlakuan 1 menghasilkan rasio $\mathrm{C} / \mathrm{N}$ yang paling tinggi yaitu $67,06 \%$. Adanya kandungan karbon yang lebih tinggi pada perlakuan 1 menghasilkan rasio $\mathrm{C} / \mathrm{N}$ yang lebih besar jika dibandingkan dengan perlakuan 2 dan 3. Menurut Ismayana, dkk., (2012), apabila nilai $\mathrm{C} / \mathrm{N}$ terlalu tinggi, mikroba akan kekurangan $\mathrm{N}$ untuk sintesis protein sehingga dekomposisi berjalan lambat.

\section{Kesimpulan}

Pengujian $\mathrm{pH}$ menunjukkan kompos yang bersifat basa. Kadar unsur hara phosfor (P), kalium (K) dan kalsium (Ca) sudah sesuai dengan ketetapan SNI, namun nitrogen $(\mathrm{N})$ dan karbon $(\mathrm{C})$ masih dibawah standar yang sudah ditetapkan oleh SNI. Hasil analisis statistik menunjukkan bahwa terdapat perbedaan pada kadar nitrogen $(\mathrm{N})$, karbon (C) terhadap variasi bahan baku kompos, sedangkan analisis statistik pada kadar phosfor $(\mathrm{P})$, kalsium $(\mathrm{Ca})$, dan kalium $(\mathrm{K})$ menunjukkan bahwa tidak terdapat perbedaan terhadap variasi bahan baku kompos. Rasio $\mathrm{C} / \mathrm{N}$ pada setiap perlakuan menunjukkan hasil yang tinggi.

\section{Ucapan Terima Kasih}

Ucapan terima kasih disampaikan kepada laboran laboratorium Pendidikan Kimia Universitas Syiah Kuala, laboran laboratorium Ilmu Tanah dan Tanaman
Fakultas Pertanian Universitas Syiah Kuala, dan laboran Balai Riset dan Standarisasi Industri Aceh yang telah membantu selama melaksanakan penelitian dan telah memberikan pelayanan dalam penelitian ini. Kemudian kepada dosen pembimbing yang telah memberikan pengarahan selama proses penelitian dan membantu dalam revisi bahasa penulisan.

\section{Daftar Pustaka}

Direktorat pembenihan dan sarana produksi direktorat jenderal hortikultura departemen pertanian. 2008. Pedoman pembuatan pupuk organik. Jakarta

Fan, Y., Lee, C., Klemes, J., Chua, L., Sarmidi, M., \& Leow, C. 2017. Evaluation of effective microorganism on home scale organic waste composting. Journal of Enviromental Management. 216:1-8

Idayati, E., Sir, W., \& Bunga, J. 2016. Minuman probiotik dari beberapa jenis kulit buah pisang dengan variasi inokulum Lactobacillus casei. Partner. 2:63-72

Irawan, B. 2014. Pengaruh susunan bahan terhadap waktu pengomposan sampah pasar pada komposter beraerasi. Jurnal Metana, 10(1):18-24

Ismayana, A., Indrasti, N., Suprihatin., Maddu, A., \& Fredy, A. 2012. Faktor rasio $\mathrm{C} / \mathrm{N}$ awal dan laju aerasi pada proses co-composting bagasse dan blotong. Jurnal Teknologi Industri Pertanian, 22(3):177

Maslahat, M., Taufiq, A., \& Subagja, P. 2015. Pemanfaatan limbah cangkang telur sebagai bisorben untuk adsorpsi logam $\mathrm{Pb}$ dan $\mathrm{Cd}$. Jurnal Sains Natural Universitas Nusa Bangsa, 5(1):92-100 
Mulyani, H. 2014. Buku ajar kajian teori dan aplikasi optimasi perancangan model pengomposan. Jakarta: CV. Trans Info Media

Nasrun, Jalaluddin, \& Herawati. 2016. Pemanfaatan limbah kulit pisang barangan sebagai bahan pembuatan pupuk cair. Jurnal Teknologi Kimia Unimal, 5(2): 19-26

Noviansyah, B., \& Chalimah, S. 2015. Aplikasi pupuk organik dari campuran limbah cangkang telur dan vetsin dengan penambahan rendaman kulit bawang merah terhadap pertumbuhan tanaman cabai merah keriting (Capsicum annum L) Var. Longum. Jurnal Bioeksperimen, 1(1):43-48

Purnomo, E., Sutrisno, E., \& Sumiyati, S. 2017. Pengaruh variasi $\mathrm{C} / \mathrm{N}$ rasio terhadap produksi kompos dan kandungan kalium $(\mathrm{K})$, pospat $(\mathrm{P})$, dari batang pisang dengan kombinasi kotoran sapi dalam sistem vermicomposting. Jurnal Teknik Lingkungan, 6(2):1-15

Rambitan, V. \& Sari, M. 2013. Pengaruh pupuk kompos cair kulit pisang kepok (musa paradisiaca l.) terhadap pertumbuhan dan hasil tanaman kacang tanah (Arachis hypogaea L.) sebagai penunjang praktikum fisiologi tumbuhan. Jurnal Edubio Tropika. 1(1):1-60

Subandryo, Anggoro, D., \& Hadyanto. 2012. Optimasi pengomposan sampah organik rumah tangga menggunakan kombinasi aktivator Em4 dan mol terhadap rasio $\mathrm{C} / \mathrm{N}$. Jurnal Ilmu Lingkungan. 10(2):7075

Syam, Z., Kasim, A., \& Nurdin, M. 2014. Pengaruh serbuk cangkang telur ayam terhadap tinggi tanaman kamboja jepang (Adenium obesum). E-Jipbiol. 3(1):9-15

Wakano, D., Samson, E., \& Tetelepta, D. 2016. Pemanfaatan limbah kulit pisang sebagai bahan olahan kripik dan kue donat di Desa Batu Merah Kota Ambon. Jurnal Biologi Science \& Education. 5(2):1-7

Widarti, B., Wardhini, W., \& Sarwono, E. 2015. Pengaruh rasio $\mathrm{C} / \mathrm{N}$ bahan baku pada pembuatan kompos dari kubis dan kulit pisang. Jurnal integritas proses. 5(2):78-79

Willar, G., Indriyati, W., \& Subamas, S. 2014. Pemanfaatan dan pengolahan limbah kulit pisang menjadi permen kulit pisang yang berkhasiat antidepresi dalam upaya pemberdayaan kesehatan dan perekonomian masyarakat Desa di Kecamatan Karang Tengah Kabupaten Cianjur. Jurnal Aplikasi Ipteks untuk Masyarakat. 3(1):5-8

Zeng, D., Zhang, Q., Chen, S., Liu, S., Chen, Y., Tian, Y., \& Wang, G. 2015. Preparation and characterizatition of a strong solid base from waste eggshell for biodiesesl production. Journal of Enviromental Chemical Engineering. 3 (1):560-564 